\title{
Death and Dying in the Works of Two Croatian Writers
}

\author{
Iva Rinčić-Lerga, M.A.pol. \\ Amir Muzur, M.D., Ph.D. \\ Rijeka University School of Medicine, Rijeka, \\ Croatia
}

ABSTRACT: The present paper elucidates the views upon death and dying expressed in the works of two Croatian writers, Dobriša Cesarić and Miroslav Krleža. Both authors' concepts are materialistic, Cesarić's being more romantic and Krleža's more expressively cruel. Neither of the two mentions any religious element or fear. The paper concludes with a suggestion of an inquiry into the influence of the works by Cesarić and Krleža upon the ideas of modern elementary school and high school generations on death and dying.

KEY WORDS: death; dying; bioethics; medicine and literature; Croatia.

Despite the aggressive advancement of other communication media more appropriate to modern life style and tempo, literature has remained an important factor in human education. It is not usual to intermingle literature, and particularly fiction, with scientifically explored topics. However, in those rare areas where science still cannot offer any answer, as in thanatology, we must search for such answers and compile them from alternative sources, such as religion, philosophy, and literature.

We believe that, when it comes to death and dying, literature can provide very interesting although sometimes opposing views that

Iva Rinčić-Lerga, M.A.pol., is in the Department of Social Sciences, Rijeka University School of Medicine, Rijeka, Croatia, where Amir Muzur, M.D., Ph.D., is with the Department of Family Medicine. Reprint requests should be addressed to Mr. sc. Iva Rinčić-Lerga, Katedra za Društvene Znanosti, Medicinski Fakultet Sveučilišta u Rijeci, Brace Branchetta 20, 51000 Rijeka, Croatia; e-mail: rinciciva@hotmail.com. 
might have great influence upon the formation of individual ethical stands. In order to test that hypothesis, we selected two prominent Croatian writers: the poet Dobriša Cesarić and the writer Miroslav Krleža.

Cesarić and Krleža were contemporaries and both characterized the Croatian literary $20^{\text {th }}$ century. They both are strongly present in all elementary school and high school programs and textbooks of literature history. Nevertheless, while Cesarić was known as an introverted romantic, detached from politics, Krleža was an extroverted, arrogant public polemicist. The ideas of the two writers, as might therefore be expected, differ significantly.

Cesarić was born in Slavonska Požega in 1902 and died in Zagreb in 1980. He started to publish poetry when he was 14 years old. Working all his life as a clerk, he contributed to several literary magazines. Although all his poems can be collected in a few booklets, the force of their formal rhymed simplicity and immediateness brought Cesaric an impressive series of prizes and inclusion in numerous important international anthologies. Translated into more than 20 languages, Cesaric might be considered the most popular Croatian poet of all times (Franges, 1987).

Krleža is one of the rare Croatian writers whose popularity and influence have surpassed the frames of national literature. Born in 1893 in Zagreb, where he also died in 1981, he left behind an imposing legacy in almost all literary genres, including poetry, drama, short stories, novels, critic, essay, and polemics; but it is hard to believe that Krleža would have earned the epithet of one of the most important personalities not only in Croatian literature but history as well, had he stayed within the realm of art only.

Early military experiences in the Austro-Hungarian army, a sojourn on the frontline in the Carpathians in 1915, a tendency toward politics that included service as a representative in Parliament, a sensibility for recognizing injustice, and his unsparing attitude toward human stupidity, criticism, and consistence in thinking and acting led to Krleža being attacked by the public or by the authorities in the turbulent periods of Croatian history. On the other hand, his active cultural and artistic life and the excellence and versatility of his literary work have secured his high position among numerous admirers, attested by the fact that Krleža has an encyclopedia of his own, the Krležijana (Viscovic, 1993-1999), while his work still provokes speculations (Lasic, 1989-1993). 


\section{Texts and Analysis}

\section{Death in Cesarić's Poetry}

Poems by Cesarić speaking about death and dying are not rare at all. Most of them are entirely devoted to that particular topic, while others consider it marginally. All the quotations below are from Slap [Waterfall] (Cesarić, 1984). The first is from his poem "When I'll be Grass":

Maybe it will be better

When one day I'll move

Into worms and earth clumps.

I will swing in merry grasses,

Poured upon with moonlight and sunshine,

Fragmented and well hidden.

Nothing will remain of my mind,

Not one thought of the dead spirit;

I will have neither ear nor hearing

To listen to the silence of my rustle.

If one day they start mowing me,

The scythe will not hurt me -

Dew will be the only load I will carry

In my new life.

The second quote is from his poem "A Song on Death":

Like winter, the summer will end completely;

And empty years will be flowing in that way,

And the sun will never smile on you -

You won't say a word to that.

The third quote is from his poem "The Dead Man":

Roses smell around him.

He is lying appeased, as if holy.

He does not feel them. Their smell

Does not reach his world.

The fourth quote is from his poem "A Dead Poet's Song":

In front of death, I hid myself (as much as I could)

Into the verses. I forged them in ardour.

But if you close your heart for them,

They are just shadow and dead letters.

Open it, and I will pass over into you

Like a copious river into a new bed. 


\section{(...)}

All my life now is in your hands.

Wake me up! We both will live

All my hours held back by verses,

All the dreams preserved from the old times.

\section{Death in Krleža's Works}

Death and dying appear as a recognizable topic of the major part of Krleža's work, disclosing the author's intensive, essential, almost instinctive revelation and description of the most hidden thoughts and fears of the human being. Such examples can be found even in the titles of Krleža's short stories, such as "The Death of Rikard Harlekini," "The Death of the Harlot Mary," "The Death of Francis the Carcase," "The Death of Florian Kranjcec," "Thousand and One Deaths," and "The Death of Tomas Bakran." Death as a topic is recognizable also in his short story collection Croatian God Mars, his drama trilogy The Glembajs Gentlefolks, his novel The Return of Phillip Latinovicz, and his collection of poetry in the Kajkavian dialect The Ballads of Petrica Kerempuh. We cannot list here all the works in which Krleža deals with death, but provide only a very limited selection of quotes that are interesting for our analysis. All quotations here are taken from his Panorama of Views, Phenomena, and Notions (Krleža, 1975).

Death itself, finally, is a simple mechanical phenomenon. The last contraction of a certain musculum, after an entire series of contractions of the same musculum following a profound law, and also: the arrest of moving, pacification. Yes! This is mechanics! A pendulum also swings and stops after a certain while. All that is mechanics and, as a matter of fact, it is more simple than it appears at a first sight. And all that happens after one deep invisible law, logically and very simply and wisely. Yes! That is death! Normal death, the arrest of a certain moving, the mechanical problem of the last pendulum....

$O$, how terrible the numerousness of our fellow-citizens would be, had not death, in its social sense, lost its immediateness. Death has bureaucratized itself, it has become a clerk act, a quotidian news, and when an obituary were what it really is - a tragedy, the man would loose his mind from that latent tragedy. The deadly theater performance lasts like in the Chinese theater: 24 hours a day, 365 performances a year....

Things decompose in death like sugar in the coffee. Actually, death is very profound: one enters it like into a well in the summer. Outside 
remain the cloudlessness, the smell of grass, while in death, it is humid and dark like on the bottom of a well. The icy breath of grave stinks from the dead mouth. And then, after all, a grotesque remains: a black house dress on the summer canvas....

\section{Discussion}

Obviously, Cesarić was not persecuted by death and did not express any fear in facing it. On the contrary, his poems on death and dying sound quite optimistic, imagining death as a state deprived of any mystic elements. For Cesarić, death was similar to dreaming, especially for its lack of the sensory input from the outside world. Interestingly, although romantic, Cesarić's concept of death was strictly materialistic, stressing the inevitability and irreversibility of dying, but also sending a message that the afterlife of a writer depends on the life of his or her work.

In the first quotation above, Krleža quite persistently denied the spiritual dimension of death and reduced death to an exclusively mechanical phenomenon. The background of that explicit reductionism could not be explained solely by the author's positivism; even the picturesque mechanistic notions and schemes of death were subdued, according to Krleža, to some "profound law." On the contrary, by "mechanizing" death, Krleža stressed its simplicity, regularity, logic, and normality, at the same time eliminating the unnecessary mystic constructions that humans, fearing the unknown, so frequently advocate.

With his thoughts on the "bureaucratization" of death, Krleža seemed almost to trace modern bioethical ideas (Grandstand, 1995; Vincent, 1980). Similar rethinking of death and dying can be found in a paper by the sociologist Ivan Cifrić, who considered how the traditional ethos included the solidarity toward the older, the sick, and the handicapped; one lived and died in a community with more or less expressed abstinence from joy in the case of death not only of a family member, but of a member of a broader community. The institutionalization, profanization, legislative regulation (death is recognized only when it is socially manifested, written, marked, and statistically described), and professionalization of death created a situation in which modern people die alone, far from their families and friends, disposed in mortuaries during the working hours and waiting for the last symbolic funerary act (Viskovic, 1993-1999). However, unlike 
modern bioethical discourse that arose as a reaction to scientific and technological progress (Lasic, 1989-1993), Krleža questioned human fears and the eternal flight from the tragedy of death.

We also found interesting also the way Krleža depicted death through a series of sensations: the almost metaphysical vanishing of sugar in the coffee; the spatial dimension of profoundness, cold, and ice; humidity, darkness, depth, and the stinking of the death well, opposed to the brightness, smell, and light of life.

There are many similarities in the views upon death and dying expressed in the works of Cesarić and Krleža. Both concepts were materialistic, Cesariç's being more romantic and Krleža's more expressively cruel. Neither concept mentioned any religious element or fear. Perhaps relevant is the fact that neither Cesarić nor Krleža had children: they both demonstrated contempt with regard to biological reproduction, and tended to overestimate their ideas and writings.

For the last several decades, Cesarić and Krleža have been heavily represented in both elementary school and high school programs in Croatia and throughout the former Yugoslavia. It would be very interesting to study in an appropriate pupil sample how much the ideas of the two classics have influenced the ideas of modern generations on death and dying. Although Cesarić and Krleža today belong to an "older" generation of writers, we believe their impressions on death and dying remain present in the ideas of younger generations. The fact that results of such a research would also be significant for the consideration of recent sociopolitical events in Croatia and of the changes in former dominant traditional attitudes and values makes further research in this field encouraging (Ilisin and Radin, 2002).

\section{References}

Cesarić, D. (1984). Slap [Waterfall]. Zagreb, Croatia: Nakladni Zavod Matice Hrvatske. Cifrić, I. (2001). Bioetika i sociologija [Bioethics and sociology]. Filozofska Istraživanja, $83,599-608$.

Franges, I. (1987). Povijest hrvatske književnosti [History of Croatian literature]. Zagreb, Croatia: Nakladni zavod Matice hrvatske.

Grandstand, G. K. (1995). Death. In W. Reich (ed.), Bioethical encyclopaedia (2 ${ }^{\text {nd }}$ ed.) (pp. 477-548). New York, NY: Free Press.

Ilisin, V., and Radin, F. (2002). Mladi uoči trećeg milenija [The young on the eve of the third millennium]. Zagreb, Croatia: Institut za Društvena Istraživanja, Državni Zavod za Zaštitu Obitelji, Materinstva i Mladeži. 
Krleža, M. (1975). Panorama pogleda, pojava i pojmova [Panorama of views, phenomena and notions]. Sarajevo, Bosnia: Oslobodenje.

Lasic, S. (1989). Krležologija [Krležology] (6 Volumes). Zagreb, Croatia: Globus.

Vincent, T. L. (1980). Antropologija smrti [Anthropology of death]. Beograd, Serbia: Prosveta.

Viskovic, V. (1993). Krležijana (2 Volumes). Zagreb, Croatia: Leksikografski Zavod Miroslav Krleža. 